Available online at: https://proceeding.researchsynergypress.com/index.php/rsfconferenceseries1

RSF Conference Series: Business, Management and Social Sciences

e-ISSN 2807-5803 |p-ISSN 2807-6699

Volume 1Number 4 (2021): 117-123

\title{
Digital Media as COVID-19 Disaster Information Literacy
}

\author{
Puji Lestari ${ }^{1}$, Titik Kusmantini' ${ }^{2}$, Yuli Chandrasari ${ }^{3}$, Devi Wening Astari ${ }^{4}$ \\ ${ }^{1}$ Communication Studies Program, Faculty of Social and Political Sciences, UPN “Veteran” Yogyakarta \\ 2Management Study Program, Faculty of Economics and Business, UPN "Veteran" Yogyakarta \\ ${ }^{4}$ Master of Communication Science, Faculty of Social and Political Sciences, UPN “Veteran" Yogyakarta \\ ${ }^{3}$ Communication Studies Program, Faculty of Social and Political Sciences, UPN “Veteran” Yogyakarta
}

\begin{abstract}
Information about COVID-19 in digital media circulating must be confirmed because there are many fake news (hoaxes). The purpose of this study was to evaluate the digital literacy curriculum of Tular Nalar Internet and Disaster Preparedness in order to reduce hoaxes among PKK RW 69 women in Perum MGA Yogyakarta. This study uses an evaluation method oriented to the program's objectives that apply Tyler's model. Evaluation is carried out in the following steps: 1) Establishing program objectives; 2) Classifying objectives; 3) Identify structured objectives; 4) Data collection through: observation, interviews. Data analysis was carried out by assessing the conditions that occurred before, during and after the implementation of the digital literacy curriculum and drawing conclusions. The results of the study show that the Tular Nalar digital literacy curriculum in the PKK RW 69 Mitra Griya Asrita community provides awareness in critical thinking. PKK women become "Tahu (know), Tanggap (respond), Tangguh (resilient)" in responding to information in disaster emergency situations.
\end{abstract}

Keywords: Hoax News; Community of PKK women; Digital Literacy; Contagious Curriculum; Internet and Disaster Preparedness

This is an open access article under the CC-BY-NC license

\section{INTRODUCTION}

Coronavirus Disease 2019 (COVID-19) is still a global pandemic with a non-natural disaster status in early 2021. COVID-19 originated in Wuhan, China in December 2019 (Zhong, Guo, \& Chen, 2020). This disease is transmitted from one human to another by attacking acute respiration, with symptoms such as fever, cough, or shortness of breath (Kaddi, Lestari, \& Adrian, 2020; Susilo et al., 2020). The high spread of COVID-19 has attracted worldwide attention, causing a lot of information to be widely spread on the internet through social networks (Zhao, Cheng, Yu, \& Xu, 2020). This is evidenced by the results of research by Kuchler, Russell, and Stroebel (2020) which state that the spread of COVID-19 information through social networks between regions occurs very quickly.

Social networks make it easy for people from all over the world to interact with each other through social media. These social media include Facebook, Twitter, WhatsApp, Telegram, Instagram, Line, and other social media (Perangin-angin \& Zainal, 2018). Social media can be an efficient and effective source of information to gain a variety of knowledge (Ahmad \& Murad, 2020), but a lot of information that is spread needs to be checked for truth because of the large number of fake news (hoaxes). The impact of hoax news about COVID-19 is on the law and divides the public (Palupi, 2020).

Any information that has not been proven to be true should not be disseminated because it creates public unrest. The public must discipline themselves to reject hoax information. This was done by the Indonesian Anti-Defamation Society (MAFINDO), together with the Maarif Institute, and Love Frankie in collaboration to offer an integrated critical thinking solution through the Tular Nalar program. Tular Nalar is a forum that provides a media literacy curriculum as a learning tool. For this reason, this research was conducted on the community of PKK RW 69 Perum MGA women, by applying the Tular Nalar Curriculum with the context of the Internet and Disaster Alert to reduce the spread of COVID-19 hoax information.

The low evaluation of the truth of news from social networks, WhatsApp groups, PKK RW 69 Perum MGA women, has led to the spread of fake news (hoax). The problem started in April 2020 when COVID- 
19 began to enter Indonesia. The untruth of the news circulating in the WhatsApp group made residents panic, restless, and have negative perceptions among residents in RW 69 of Perum MGA. This needs to be addressed immediately by educating the community of PKK RW 69 women, through the implementation of the Internet and Disaster Preparedness Curriculum.

This is related to McLuhan's Media Ecological Theory (Ratana, 2018), namely: 1) Media influences every community action. According to the research results of Ryan, Allen, Gray, \& McInerney (2017) that the media contradicts actual social relationships, so that it can reduce the level of friendship and physical community action; 2) Media improve perception by managing the individual's experience. Research by Wackowski, Manderski, Lewis, \& Delnevo (2019) shows that individuals can change perceptions when messages read from a media affect their feelings; and 3) Media bind the world together. The results of research by Limaye et al. (2020) states that the impact of COVID-19 requires people to keep their distance from each other and even lock down areas or countries, use the internet, especially social media to interact with each other and share information. The media binds the community together and is not hindered by distance in the face of disasters.

Every individual has a vulnerability in the face of disasters. One of the social radars when a disaster occurs in a certain area is through communication. Communication refers to the actions of one or more people sending and receiving messages that have a certain effect. Communication that occurs during a disaster can be referred to as disaster communication. Disaster communication provides information to the public regarding preparedness that needs to be prepared in terms of action and treatment when a disaster occurs (Lestari, 2018). Disaster communication is needed to create a disaster-resilient community that is ready to survive in the face of disaster threats (Lestari, Ritonga, Ruliana, \& Barus, 2020).

Disasters can be natural or non-natural. In this study, the disaster that is being experienced is a nonnatural disaster COVID-19, so that the response to COVID-19 is carried out with a hard power approach. The hard power approach is an effort to deal with disasters by carrying out physical development in the form of facilities and infrastructure, including digital communication media facilities (Lestari, 2020). This research supports a hard power approach to disaster management through the Internal Communication and Disaster Preparedness Curriculum, so that the community has a strong foundation in responding to disaster issues through social media.

The novelty of this study compared to previous research is that this study uses the method of evaluating the Internet and Disaster Preparedness Curriculum in the community of PKK RW 69 Perum MGA Yogyakarta women whose information literacy level is still low. This study aims to evaluate the Tular Nalar Internet and Disaster Preparedness digital literacy curriculum to reduce hoaxes among PKK RW 69 Perum MGA women.

\section{LITERATURE REVIEW}

\section{Digital Literacy}

The rapid growth and the number of media phenomena are no longer enough to solve various digital literacy problems. Literacy can be interpreted as an ability to read and write. Jones \& Hafner $(2013,13)$ define digital literacy as the practice of communicating, relating, thinking, and 'being' related to digital media. Digital literacy is the ability to understand and use information through various digital sources. So simply digital literacy can be interpreted as a skill to understand and use information in the digital era (Kurnia \& Astuti, 2017).

In this digital era, social media is one of the most widely used social networks in Indonesia. The behavior of these social media users ultimately raises various news or hoax information. Allcott and Gentzkow (2017) define hoax as news that does not contain factual basis but is presented as truth. Combating fake news on social media has resulted in less trust in headlines. So the ability to understand and use information in the digital era needs to be improved, so that people are not easily exposed to hoax information or news. 


\section{Tular Nalar}

Tular Nalar is present in the form of an online learning portal. Tular Nalar is a place that provides media and digital literacy curriculum as a learning tool based on each context. Tular Nalar is a consortium between MAFINDO, MAARIF Institute and Love Frankie since October 2020. (Palupi, 2021). Supported by Google.org, and in strategic partnership with KOMINFO, Ministry of Education and Culture, Ministry of Religion, ASPIKOM, Muhammadiyah, and Cyber Kreasi. (tularnalar.id)

Tular Nalar has 8 curriculum experts with different competencies. The eight experts are Dr. Syarifah Ema Rahmaniah, M.Sc., Dr. Puji Lestari, M.Sc., Dr. Novi Kurnia, PhD, Dr. Arnidah Kanata, M.Sc., Fanny S. Alam, Gilang Adikara, M.Sc., Dr. Ni Made Ras Amanda, M.Sc., and Ramaditya Adikara. (Rido, 2020). Where Tular Nalar provides various media and digital literacy materials or curricula to train critical thinking that can be applied in real life.

The Tular Nalar digital literacy curriculum in this study focuses on the Community of PKK RW 69 MGA. Where during non-natural disasters such as COVID-19 today, the flow of information dissemination leads to hoaxes. For this reason, an understanding of digital literacy and Disaster Preparedness is very necessary. Tular Nalar's digital literacy curriculum is expected to transmit common sense to make judgments in preparing decision making from circulating information. The community is expected to be "Tahu, Tanggap, Tanggup" when it comes to managing information during a disaster emergency.

\section{Critical thinking}

Critical thinking is a process and ability used to be able to understand, apply, synthesize and evaluate the information obtained and produced. Critical thinking is evaluative thinking that specifically has a relationship with the quality of arguments, thoughts that are presented to support a series of actions, with indicators: identifying, assessing, interpreting, analyzing, arguing, evaluating, and concluding (Fisher, 2008). Critical thinking can be learned, estimated and taught. Facione (2015) explains that critical thinking becomes a self-regulation to decide something that results in interpretation, analysis, evaluation, inference, presentation of a concept, evidence, methodology, criteria that are the basis for decision making. More simply, critical thinking is making reasonable judgments (Bayer, 1995).

Critical thinking is important as a life skill that becomes a source of strength in one's personal and social life. Thinking activities have a relationship with self-organization or self-management, so that every individual has the potential to become a critical thinker. So with the development of digital media today, people must continue to develop themselves to think critically. Tular Nalar is a means of public education to improve critical thinking skills. Especially in the non-natural disaster situation of Covid-19, a lot of information circulates and can potentially cause hoaxes that are disturbing to the community.

\section{RESEARCH METHODOLOGY}

This study uses a continuous evaluation method to check, observe, and measure the extent to which the objectives of this research have been achieved in the program implementation process. The evaluation method applied in this study is Tyler's Evaluation Model because this model is relatively simple and easy to understand. The steps in the evaluation process of this research (Aw, 20-19), are: 1) Establishing the objectives of the Contagious Curriculum program with the theme of the Internet and Disaster Alert to educate the public as a basis for responding to the COVID-19 disaster issue which has an impact in the form of non-structural mitigation; 2) Classifying research objectives for evaluating the Tular Nalar digital literacy curriculum for the community of PKK RW 69 Perum MGA women in reducing hoaxes for the COVID-19 disaster; 3) Collecting data at Perum Mitra Griya Asri, RW 69.

The data were collected by: (1) Observing the implementation of the Tobacco Curriculum program, viewed from the aspects: a) Knowledge of the community of PKK women regarding the Tobacco Curriculum; b) Attitude, community response of PKK women when receiving hoax information; and c) the behavior of PKK women in spreading digital media hoax news; (2) Interviews with the chairperson and members of the PKK regarding the evaluation of the results of the implementation of the Tular Nalar curriculum. Interviews with community leaders, RW officials regarding curriculum socialization to 
reduce the spread of hoax information; (3) Focus Group Discussion (FGD) on the Contagion of Reason Curriculum with community leaders, leaders and community members of PKK RW 69 MGA women. The data collected through FGDs include: 1) Information on matters that need to be considered when receiving and disseminating disaster information; 2) Information regarding the official COVID-19 website; 3) Information regarding the characteristics of disaster hoax information; 4) The formulation of digital literacy through the Tular Nalar curriculum through the PKK women community; (4) Simulation of the Contagion of Reason curriculum through socialization of the Congenital Reason curriculum with the community of PKK RW 69 MGA women.

The data that has been collected is analyzed by: a) Logical Method, which is to assess the situation that occurs when implementing the curriculum with logical considerations; b) Empirical Method, namely the conclusion is the result of the research which later becomes an important part of the essence of the research. The results of the analysis are in the form of a digital literacy model through the Tular Nalar curriculum through the community of PKK RW 69 women.

\section{FINDING AND DISCUSSION}

The results of the study found various information on the evaluation results of the Internet and Disaster Preparedness Curriculum to reduce hoaxes among PKK RW 69 Perum MGA women. The researcher carried out the goal-setting stage of the program that had been carried out on June 20, 2021 to educate the public as a basis for responding to disaster issues, especially related to the COVID-19 disaster. The purpose of the implementation is to evaluate the Tular Nalar curriculum in the community of PKK RW 69 Perum MGA women. Participants conducted discussions with 20 quizzes consisting of 5 analyzes of hoax information or not, 5 analyzes of statements that were true or not, and 10 analyzes of the JAPELIDI campaign poster against hoaxes.

The results of the Focus Group Discussion conducted by researchers on June 20, 2021, showed that cellphones (HP) are the basic needs of most people. The social media that is often used is WhatsApp, but there are many hoaxes that spread from social media. The head of the PKK women at RW 69 MGA, Mrs. Viktor, stated that one of the hoax news that had been received was about the Panti Rapi Hospital room which was full of COVID-19 patients. The fact is not like the information received.

Speaker Dr. Novi Kurnia gave group quizzes with 2-3 participants to provide opinions related to certain cases. One of the groups chaired by Ivan got a case of clickbait hoax related to cases in Australia that many died after being vaccinated. A similar case discussed was related to 10 doctors who died within 1 x 24 hours after the vaccine in September. In fact, doctors did not die within 1 x 24 hours at the same time and not because of the vaccine because at that time there was no vaccine in Indonesia. Next, the case discussed regarding the thermo gun that can damage the brain. The fact is that the thermo gun does not damage the brain because it is only a tool to check someone's body milk. Another case is related to acting quietly when receiving hoaxes in a chat group, one group stated that:

"When we get hoax news in any chat group, we should not be silent. If we are silent, it is a wrong action. If we already know the news is a hoax, we must prevent it or we send the real information. By preventing hoaxes, it means that we care about ourselves and the environment around us" (Pak Anang and Mas Bowi, 20 June 2021)

The public must indeed have a concern for themselves and the surrounding environment to prevent the circulation of hoaxes by providing information that has clear and reliable sources. The next statement that was discussed was related to the right of every citizen to speak and have an opinion, where when there was hoax news it was justified. One group stated that it is not good to immediately spread information to make it look up to date by others, because it actually leads to hyperbole. Dr. Novi Kurnia says:

"It's true, spreading the news quickly is not the right attitude, because the speed in spreading the news is not the main thing. The main thing is to verify the facts of the news. We need to verify the truth of the news, see if the source is clear or not. Don't be rash, don't share right away. The important thing that we need to understand is that it is an important post, not an important post" (Dr. Novi, 20 June 2021) 
Another attitude is not to panic if you receive hoax news, you have to go through a new filtering process for sharing. The next case is related to the body of COVID-19, don't reject it, many of the participants agreed. It's just that the burial was carried out in accordance with the COVID-19 Standard Operating Procedure (SOP). The next case regarding accompanying children to study at home received an agreeable response because children must continue to receive education during the pandemic, even though online. The next case related to the hospital ward was extended by providing an ID card number. The results of the discussion show that this is a hoax, because the public must protect personal data and it can be misused by irresponsible persons. Confused cases related to COVID-19 drugs were also discussed, one of the participants, Mrs. Samino, stated that it was hoax information, because the prescription for the drug was not clear.

Participants were also asked to discuss posters to help COVID-19 patients. The participants agreed to help because patients need support from the environment by showing concern in order to speed up the healing process. Caring and support can increase the positive aura for healing. Participants also discussed about posters for donations, so that they should not be misused by irresponsible parties. It is better not to contain the patient's personal information, because it violates the law and can cause psychological disturbance to the patient.

The results of the FGD showed that the three ideas of McLuhan's Media Ecological Theory (Ratana, 2018), were proven in the implementation of the Contagious Reason curriculum in the community of PKK RW 69 MGA women. Namely: 1) The media influences every action of PKK RW 69 women. Before being given education about digital literacy, it was easier to believe hoax news. After being educated, the community first investigates a clear source; 2) The media improve perceptions by managing experience, it can be seen that after digital literacy education was carried out, PKK RW 69 women who received hoaxes filtered information first by validating data, then sending back information with accurate and reliable sources; 3 ) The media binds the world together, as seen through posters containing sentences that strengthen COVID-19 patients who are considered to be able to improve their immunity better. No need to meet face to face, just by giving encouragement through social media for the whole world without limits.

The results of the study strengthen the research conducted by Rahadi (2017), namely to prevent the flow of hoax information from getting stronger, it can be done by increasing public literacy which is supported by the active role of the government, community and community leaders, in providing easy access to correct sources of information on every issue, hoax issues, conducting systematic and continuous education and effective legal action for the spreaders. The implementation of the Tular Nalar curriculum to the community of PKK RW 69 women becomes "Tahu, Tanggap, Tangguh". PKK women "Tahu" the difference between fake news or not. Then be "Tanggap" to the confusion of information that can harm others. In the end, the community became "Tangguh" in managing information in disaster emergency situations, by committing not to create and spread hoax news.

\section{CONCLUSSION AND FUTHER RESEARCH}

This research contributes in the form of input on the evaluation results of the Internet Contagion Curriculum and Disaster Preparedness in the community of PKK women RW 69 Perum MGA Yogyakarta to reduce the spread of hoax information through critical thinking. The result of critical thinking, people become "Tahu, Tanggap, Tangguh" in accordance with the Tular Nalar. PKK women "Tahu" which news is hoax or not. After finding out, the community became "Tanggap" by realizing that hoax news was felt to be detrimental to many parties. In the end, the community became "Tangguh" by having a commitment to collaborate not to produce and spread COVID-19 hoax news.

\section{REFERENCE}

Ahmad, A. R., \& Murad, H. R. (2020). The Impact of Social Media on Panic During the COVID-19 Pandemic in Iraqi Kurdistan: Online Questionnaire Study. Journal of Medical Internet Research, 22(5), 1-11. https://doi.org/10.2196/19556

Allcott, Hunt. Gentzkow, Matthew. (2017). Social Media and Fake News in the 2016 Election. Journal of Economic Perspective. 31(2) 
RSF Conference Series: Business, Management and Social Sciences

Volume 1Number 4 (2021): 117-123

Digital Media as COVID-19 Disaster Information Literacy

Puji Lestari, Titik Kusmantini, Yuli Chandrasari, Devi Wening Astari

Aw, S. (2019). Perencanaan \& Evaluasi Program Komunikasi. Yogyakarta: Pena Pressindo.

Beyer, B.,K. 1995. Critical Thinking. Bloomington: Phi Delta Kappa Educational Foundation

Fisher, A. 2007. Berpikir Kritis: Sebuah Pengantar. Terjemahan oleh Benyamin Hadinata. 2008. Jakarta: Erlangga.

Facione, Peter. (2015). Critical Thinking: What It Is and Why It Counts. Insight Assesment. 1-30.

Jones, Rodney H. \& Hafner, Christoph A. (2012). "Understanding Digital Literacies: A practical introduction". Oxford: Routledge.

Kaddi, S. M., Lestari, P., \& Adrian, D. (2020). Komunikasi Keluarga Dalam Pencegahan Coronavirus Disease 2019. Jurnal Ilmu Komunikasi, 18(1), 63-74. https://doi.org/10.31315/jik.v18i1.3701

Kuchler, T., Russel, D., \& Stroebel, J. (2020). the Geographic Spread of Covid-19 Correlates With Structure. NBER Working Paper Series, (26990). Diambil dari http://www.nber.org/papers/w26990

Kurnia, N., \& Astuti, S. I. (2017). Peta Gerakan Literasi Digital Di Indonesia : Studi Tentang Pelaku, Ragam Kegiatan, Kelompok Sasaran Dan Mitra Informasi, 47(2), 149-166.

Lestari, P. (2018). Komunikasi Bencana: Aspek Penting Pengurangan Risiko Bencana. Yogyakarta: PT. Kanisius.

Lestari, P. (2020). Internet dan Siaga Bencana. Diambil 3 Maret 2021, dari https://tularnalar.id/lessons/07-internet-dan-siaga-bencana/

Lestari, P., Ritonga, R., Ruliana, P., \& Barus, C. C. B. (2020). Disaster Communication Uses Field Training Exercise Simulation as an Important Aspect of Disaster Risk Reduction. Jurnal Komunikasi: Malaysian Journal of Communication, 36(24), 166-186. https://doi.org/doi.org/10.17576/JKMJC-2020-3601-10

Limaye, R. J., Sauer, M., Ali, J., Bernstein, J., Wahl, B., Barnhill, A., \& Labrique, A. (2020). Building trust while influencing online COVID-19 content in the social media world. The Lancet Digital Health, 2(6), e277-e278. https://doi.org/10.1016/S2589-7500(20)30084-4

Palupi, M. T. (2020). Hoax: Pemanfaatannya Sebagai Bahan Edukasi Di Era Literasi Digital Dalam Pembentukan Karakter Generasi Muda. Jurnal Skripta, 6(1), 1-12. https://doi.org/10.31316/skripta.v6i1.645

Palupi, Yvesta Putu Ayu. 2021. Kurikulum Tular Nalar Tingkatkan Literasi Digital. Diambil 19 Agustus 2021, dari https://news.koranbernas.id/kurikulum-tular-nalar-tingkatkan--literasi-digital--

Perangin-angin, L. L. K., \& Zainal, M. (2018). Partisipasi Politik Pemilih Pemula Dalam Bingkai Jejaring Sosial Di Media Sosial. Jurnal ASPIKOM, 3(4), 737. https://doi.org/10.24329/aspikom.v3i4.210

Permani, A. W. (2020). Sebarkan Hoax Virus Corona, Ibu Rumah Tangga di Surabaya Ditangkap Polisi. Diambil 3 Maret 2021, dari https://www.suarasurabaya.net/kelanakota/2020/sebarkan-hoaxvirus-corona-ibu-rumah-tangga-di-surabaya-ditangkappolisi/?_cf_chl_captcha_tk_=02204e6659c1c9ba2f81c7467046028c1cb9710d-1614748877-0AV2RY-s082MMIWHteG3OHWmGReK76nVVac8twxE-vYKR9Y7zl3GZ2P7u-9l

Rahadi, Dedi Rianto. (2017). Perilaku Pengguna dan Informasi Hoax di Media Sosial. Jurnal Manajemen dan Kewiravsahaan JMDK, 5 (1), 58-70

Ratana, M. (2018). Pengaruh Social Media Marketing Terhadap Ekuitas Merek. Jurnal Studi Komunikasi dan Media, 22(1), 13. https://doi.org/10.31445/jskm.2018.220102

Rido, Kuntoro. (2020). Tular Nalar Show:Launching Kurikulum dan Bincang-bincangPakar Tular Nalar. Diambil 19 Agustus 2021, dari https://beritajatim.com/pendidikan-kesehatan/tular-nalarshow-launching-kurikulum-dan-bincang-bincang-pakar-tular-nalar/

Ryan, T., Allen, K. A., Gray, D. L. L., \& McInerney, D. M. (2017). How Social Are Social Media? A Review of Online Social Behaviour and Connectedness. Journal of Relationships Research, 8(e8), 1-8. https://doi.org/10.1017/jrr.2017.13 
RSF Conference Series: Business, Management and Social Sciences

Volume 1Number 4 (2021): 117-123

Digital Media as COVID-19 Disaster Information Literacy

Puji Lestari, Titik Kusmantini, Yuli Chandrasari, Devi Wening Astari

Susilo, A., Rumende, C. M., Pitoyo, C. W., Santoso, W. D., Yulianti, M., Herikurniawan, H., ... Yunihastuti, E. (2020). Coronavirus Disease 2019: Tinjauan Literatur Terkini. Jurnal Penyakit Dalam Indonesia, 7(1), 45. https://doi.org/10.7454/jpdi.v7i1.415

Tular Nalar, 2021, Periksa Fakta, Sadar Data Sebelum Bicara, https://tularnalar.id/

Vellingiri, B., Jayaramayya, K., Iyer, M., Narayanasamy, A., Govindasamy, V., Giridharan, B., ... Subramaniam, M. D. (2020). COVID-19: A promising cure for the global panic. Science of The Total Environment, 725(138277), 1-18. https://doi.org/10.1016/j.scitotenv.2020.138277

Wackowski, O. A., Manderski, M. T. B., Lewis, M. J., \& Delnevo, C. D. (2019). The Impact of Smokeless Tobacco Risk Information on Smokers' Risk Perceptions and Use Intentions: A News Media Experiment. Health $\quad$ Communication, 34(3), 325-332. https://doi.org/10.1080/10410236.2017.1407226

Zhao, Y., Cheng, S., Yu, X., \& Xu, H. (2020). Chinese public's attention to the COVID-19 epidemic on social media: Observational descriptive study. Journal of Medical Internet Research, 22(5), 1-13. https://doi.org/10.2196/18825

Zhong, P., Guo, S., \& Chen, T. (2020). Correlation between travellers departing from Wuhan before the Spring Festival and subsequent spread of COVID-19 to all provinces in China. Journal of travel medicine, 27(3), 1-4. https://doi.org/10.1093/jtm/taaa036 